\title{
COMPARATIVE STUDY OF USING AUTOGENOUS FASCIA LATA SLING VERSUS BANKED HUMAN SCLERA SLING FOR CORRECTION OF CONGENITAL PTOSIS
}

\author{
By \\ Hazem El-Badry Mohamed, Hosny Hassan Mohammd and Omar Hassan \\ Salama \\ Department of Ophthalmology, Faculty of Medicine, Al-Azhar University, Cairo, Egypt \\ E-mail: ophthalomologisthazem@gmail.com
}

\begin{abstract}
Background: Congenital ptosis has physical, functional, and psychological consequences. The method of repair depends on treatment goals, the underlying diagnosis, and the degree of levator function which is the most important eyelid measurement in term of surgical planning. Frontalis suspension surgery is well accepted as the procedure of choice for patients (congenital or acquired etiologies) with severe ptosis and poor levator function. Autologous fascia lata is considered one of the best materials for Frontalis suspension surgery due to its low complications rate and long term viability and compatibility, but due to long operative time other natural materials may be used as human scleral graft.
\end{abstract}

Objective: To compare surgical efficacy of using autogenous fascia lata sling versus banked human sclera sling for correction of congenital ptosis with poor levator function.

Patients and Methods: A randomized prospective comparative pilot study was conducted on forty eyelids in 26 patients with ptosis associated with poor levator function. Patients were examined, operated upon and followed up at Al-Azhar university hospitals in Cairo during the period from March 2019 till December 2020. Patients were divided into two equal groups: Group A included eyelids in 13 patients (7 bilateral \& 6 unilateral), corrected by frontalis sling using autologous fascia lata Group B included eyelids in 13 patients ( 7 bilateral \& 6 unilateral), corrected by banked scleral graft sling. Patients were prepared by taking full history, complete ophthalmic examination, ptosis assessment by measuring margin reflex distance [MRD1], palpebral fissure height $[\mathrm{PFH}]$, levator function, and Lid crease. Lid position on down gaze, cover test and Bell's phenomenon were also assessed. Functional outcomes (MRD1 \& PFH) and cosmetic outcomes (Symmetry, lid crease and contour) and complication rates were compared.

Results: After a follow up period of at least 6 months, postoperative outcomes showed no statistically significant difference regarding MRD1 and PFH. Percentage of excellent cosmetic outcomes for group A regarding lid contour was $70 \%$, lid height symmetry $75 \%$ and lid crease appearance was $80 \%$. Corresponding figures for group B patients were 60\%, $65 \%$ and $65 \%$ respectively. None of cases had recurrence or serious complications.

Conclusion: Banked scleral graft in frontalis suspension has comparable results to the autologous fascia lata with the advantages of shorter operative time and avoiding the need for a second surgical site with its potential morbidity. Longer follow up period is required to confirm whether scleral slings will confer long lasting ptosis correction.

Key Words: Fascia lata sling, Banked human sclera sling, congenital ptosis. 


\section{INTRODUCTION}

Ptosis, or drooping of the eyelid, is a common oculoplastic disorder causing functional and esthetic problems. Surgery is required to correct ptosis, and levator muscle function (LF) is the most important factor in selection of the type of ptosis surgery. When the LF is fair to good, a levator resection operation is performed, whereas a frontalis suspension operation is needed for patients with poor LF (Kim, 2017).

Simple congenital ptosis is the most frequent type of ptosis in children resulting from partial or complete loss of levator muscle function mainly caused by mal development of the levator muscle (Zhang et al., 2011).

Levator function is graded as normal (15 mm or more), good (12-14 mm), fair $(5-11 \mathrm{~mm})$ or poor (4 $\mathrm{mm}$ or less) (Kanski and Bowling, 2011).

In frontalis suspension surgery, several sling materials are available such as fascia lata and scleral graft, whether autogenous or banked, or synthetic materials like extended polytetrafluoroethylene (GoreTex), polypropylene, nylon, silicone, and mersilene. Synthetic sling materials are more readily available and are not associated with donor-site morbidity or cross-infection possibility. However, synthetic materials are believed to have a higher recurrence rate and risk of extrusion, infection, granuloma formation, and breakage after trauma (Zaky et al., 2017).

Frontalis suspension using autogenous fascia lata is the gold standard procedure as regard it has a long-term effect for elevating the upper eyelid. In addition, it generates and allows the development of the fibrovascular tissue (Debski et al., 2012).

There is no general agreement on sling configuration: Single/ double, rhomboid, pentagonal, or triangular methods can be used. Some believe that the monotriangular method is best for peaked brows and the pentagon or rhomboid type is preferred for diffuse, elevated brows. Others recommend monotriangular (modified Fox method) for children and bitriangular (modified Crawford method) for adults (Nasr et al., 2012).

The present work aimed to compare surgical efficacy of using autogenous fascia lata sling versus banked human sclera sling for correction of congenital ptosis with poor levator function.

\section{PATIENTS AND METHODS}

Forty eyelids in 26 patients with ptosis associated with poor levator function were included in this study and randomly divided into two groups:

Group A: Included 20 eyelids in 13 patients (7 bilateral and 6 unilateral), corrected by frontalis sling using autologous fascia lata.

Group B: Included 20 eyelids in 13 patients (7 bilateral and 6 unilateral), corrected by frontalis sling using banked scleral graft.

Patients were examined, operated upon and followed up at Al-Azhar University Hospitals in Cairo during the period from March 2019 till December 2020. All patients submitted to detailed preoperative history taking and ophthalmic examination. 


\section{Ptosis assessment:}

Margin reflex distance (MRD1), palpebral fissure height $(\mathrm{PFH})$, levator function, Lid crease: presence or absence of the lid crease was documented, lid position on down gaze and cover test. For unilateral and bilateral unequal cases; contralateral accentuation was also checked. Corneal sensation and Bell's phenomenon was also assessed. Review of old photographs of the patient whenever these were available.

\section{Inclusion criteria:}

1. Unilateral or bilateral simple isolated congenital ptosis.

2. Levator function less than $4 \mathrm{~mm}$.

\section{Exclusion criteria:}

1. Patients with certain ophthalmic problems: Restrictive strabismus, Horner's syndrome and jaw-winking phenomenon.

2. Patients with poor protective mechanisms: Defective corneal sensation, dry eyes and absent Bell's phenomenon.

3. Good levator function.

4. Patients with myopathies.

5. Patients with uncontrolled chronic diseases.

6. Exclusion criteria of scleral graft included: Death of unknown cause, CNS infectious diseases, systemic infections (AIDS, hepatitis, syphilis and septicemia), leukemia, lymphoma and intrinsic eye diseases.

Frontalis sling suspension was done using triangular sling design (Figure 1). Sling material stringing was performed using Wright needle. We used a commercially available non- absorbable polyester green braided 5-0 USP (Astralen ${ }^{\circledR}$ ) to fixate slings to the tarsus and frontalis muscle.

The sling material used was autologous fascia lata for group (A) and banked scleral graft for group (B).

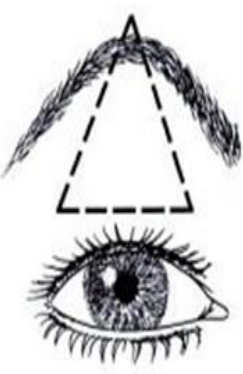

Figure (1): Triangular sling design.

\section{Harvesting fascia lata (Figure 2):}

Under general anesthesia, with the knee and hip in flexion on one side, an incision $1 \mathrm{~cm}$ was made in the skin and subcutaneous tissues on the lateral thigh starting about $6 \mathrm{~cm}$ above the lateral tibial condyle, and another incision was done 12 $\mathrm{cm}$ from the first one toward the anterior superior iliac spine. The incision was deepened till the fascia lata was identified as a white glistening tissue with fibers running parallel to the axis of the thigh. Blunt dissection was then carried out above and below the whole length of the 
strip, using long straight scissors, to free it completely, the upper end of the strip was then cut. About $2 \times 12 \mathrm{~cm}$ facial strip was then harvested (figure 2).

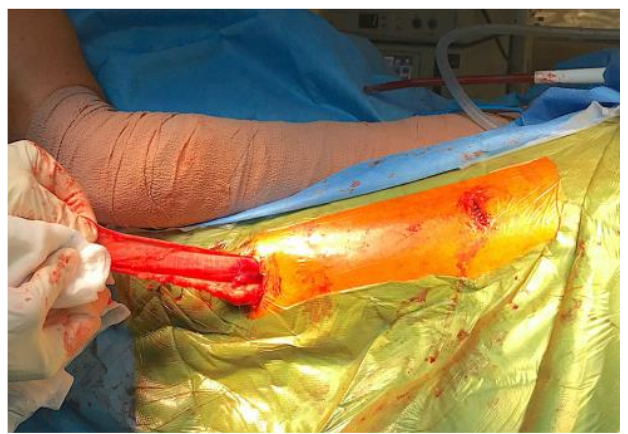

Figure (2): Fascia lata graft presented through the proximal skin incision

Fascial strips were cleaned of unwanted tissue and cut in $3 \mathrm{~mm}$ wide strips (Figure 3).

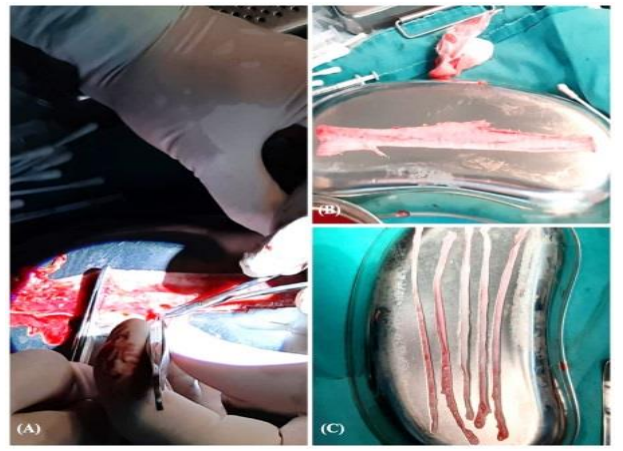

Figure (3): Fascia lata strip after harvesting process, A) Cleaning of fasica lata of attached tissues. B, C) Remodeling and fashioning of the fascia lata strip into thin $3.0 \mathrm{~mm}$ width strips.

\section{Preparing banked scleral graft:}

Human scleral strips seemed particularly suitable because they were (1) homografts and likely to be accepted by the host, (2) readily available from eye banks, (3) easily worked with, (4) amenable to sterilization (5) preservable, and (6) sufficiently strong. Experience supported these theoretic considerations (Bodian, 1968).

Banked human scleral sling was obtained from scleral ring remnant of a corneo-scleral button after penetrating Keratoplasty (PKP) at same or next day. The scleral ring was preserved in the same storage media in a refrigerator till the time of surgery. Data of the corneo-scleral button were revised to confirm that the corneoscleral button was removed within 24 hours of death.

The scleral ring was rehydrated with physiological saline for several minutes then soaked in an antibacterial ophthalmic solution (Neomycin-Polymycin-Bacitracin combination) for several minutes. Preparation was done under sterile conditions, in the operating room just prior to surgery.

Corneal remnants were removed, the scleral ring was grasped with a fine- 
toothed forceps then cut in a spiral mm wide (Figure 4). fashion, producing a long thin strip 2-3

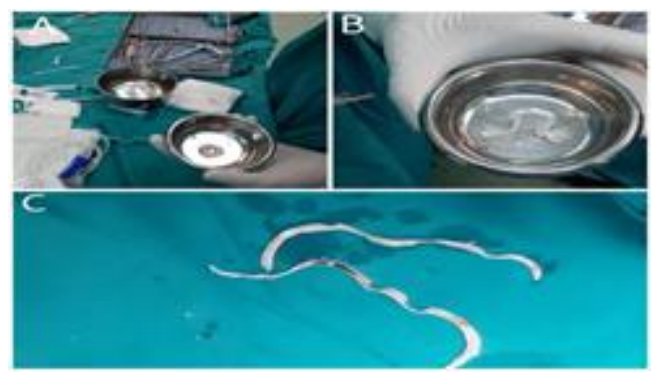

Figure (4): A) Sclera after removal of Corneal Graft B) Removal of Corneal remnant from edges of Sclera C) Scleral shell has been grasped with forceps, and scissors are used to cut $5 \mathrm{~mm}$ scleral strip in spiral fashion.

\section{Surgical steps:}

Choose of lid crease postion:

Unilateral Cases: crease was Chosen Corresponding to opposite Side.

Bilateral Cases: The incision sites were marked above the lash line $7 \mathrm{~mm}$ in males, $9 \mathrm{~mm}$ in females Skin crease mark extended from the upper punctum to the lateral canthus.

\section{Forehead Incision:}

Site: Above the hair line. Size: $6-8 \mathrm{~mm}$.

The central part of the sling strip was fixated to the tarsus by the preplaced sutures leaving equal free limbs.

Both limbs of the sling were retrieved through the eyebrow incision; eyelid contour and height were checked by pulling on the ends of sling material.

Both ends of the sling were tied together, and the knot was secured with the preplaced polyester 5-0 suture to avoid slippage.

Ends of sling material were buried into a tunnel dissected underneath the frontalis muscle. Data Management and Analysis:

Statistical Analysis: The collected data was revised, coded, tabulated and introduced to a PC using Statistical package for Social Science (SPSS 15.0 for windows; SPSS Inc, Chicago, IL, 2001).

Descriptive statistics: Mean, Standard deviation ( \pm SD), Minimum and maximum values (range) for numerical data, Frequency and percentage of nonnumerical data.

Analytical statistics: mann whitney test, Paired-Samples T Test, The IndependentSamples T Test, Chi-Square test and Fisher's exact Chi-Square test. 


\section{RESULTS}

Patient Demographics: Group A included 10 male $(76.9 \%)$ and 3 females (23.1\%) while Group B included 6 males $(46.2 \%)$ and 7 females (53.8\%) Mean age was $8.53 \pm 4.08$ years in Group $A$ and $8.31 \pm 3.14$ years in Group B Age and sex distributions in both groups were comparable, age was distributed as $8.42 \pm 2.85$ and $8.07 \pm 2.59$ with no significant difference between groups, and
Operative time for each eyelid including the time for harvesting fascia lata was $41.75 \pm 3.04$ minutes in Group $\mathrm{A}$ and $19.85 \pm 2.08$ minutes in group B.

There was no statistically significant difference between the studied groups in regard to gender and age while There was statistically highly significant difference between the studied groups in regard to operative time (Table 1).

Table (1): Comparison between the studied groups as regard gender, age and operative time:

\begin{tabular}{|c|c|c|c|c|c|c|}
\hline \multirow{2}{*}{$\begin{array}{l}\text { Parameters } \\
\text { Groups }\end{array}$} & \multicolumn{2}{|c|}{ Gender } & \multicolumn{2}{|c|}{ Age } & \multicolumn{2}{|c|}{ Operative time } \\
\hline & Male & Female & Mean & SD & Mean & SD \\
\hline Group A $(n=13)$ & $10(76.9 \%)$ & $3(23.1 \%)$ & 8.53 & 4.08 & 41.75 & 3.04 \\
\hline Group B $(n=13)$ & $6(46.2 \%)$ & $7(53.8 \%)$ & 8.31 & 3.14 & $\mathbf{1 9 . 8 5}$ & 2.08 \\
\hline Total $(n=26)$ & $16(61.5 \%)$ & $10(38.46 \%)$ & & & & \\
\hline$P$ value & \multicolumn{2}{|c|}{0.273} & \multicolumn{2}{|c|}{0.87} & \multicolumn{2}{|c|}{$<0.001$} \\
\hline
\end{tabular}

Change in Palpebral Fissure Height (PFH):

Mean preoperative palpebral fissure height in group A was $3.84 \pm 0.95 \mathrm{~mm}$, which increased to $8.105 \pm 0.73 \mathrm{~mm}$ after $6 \mathrm{~m}$ from surgery. Corresponding figures for group B were $4.35 \pm 0.81 \mathrm{~mm}$ and $8.10 \pm 0.85 \mathrm{~mm}$ respectively. Both groups significantly increased Palpebral fissure height increased by $4.05 \pm 1.23 \mathrm{~mm}$ in group $A$ and $3.75 \pm 1.06 \mathrm{~mm}$ in group $B$ the intergroup difference was not statistically significant.

\section{Change in Margin Reflex Distance 1 (MRD1):}

Mean preoperative Margin Reflex Distance in group A was $-0.79 \pm 1.21 \mathrm{~mm}$, which increased to $3.52 \pm 0.84 . \mathrm{mm}$ after surgery. Corresponding figures for group B were $-0.42 \pm 0.86 \mathrm{~mm}$ and $3.35 \pm 0.67 \mathrm{~mm}$ respectively. MRD1 in both groups significantly increased. Upper eyelid margin reflex distance increase was $4.10 \pm 1.25 \mathrm{~mm}$ in group $\mathrm{A}$ and $3.80 \pm 1.10$ $\mathrm{mm}$ in group $\mathrm{B}$, which was statistically insignificant between groups.

The mean postoperative PFH and MRD were higher than preoperative $\mathrm{PFH}$ and MRD among group A \& B. These differences were statistically highly significant (Table 2). 
Table (2): Comparison between the studied groups regard to PFH, MRD and intergroup difference in PFH and MRD (Mean \pm SD)

\begin{tabular}{|c|c|c|c|c|c|c|c|c|c|}
\hline \multirow{2}{*}{ Parameters } & \multicolumn{3}{|c|}{ Group A $(n=13)$} & \multicolumn{3}{|c|}{ Group B $n=13$ ) } & \multicolumn{3}{|c|}{ Intergroup Difference } \\
\hline & $\begin{array}{c}\text { Pre- } \\
\text { operative }\end{array}$ & $\begin{array}{c}\text { Post- } \\
\text { operative }\end{array}$ & $\begin{array}{c}P . \\
\text { Value }\end{array}$ & $\begin{array}{c}\text { pre- } \\
\text { operative }\end{array}$ & $\begin{array}{c}\text { post- } \\
\text { operative }\end{array}$ & $\begin{array}{c}P . \\
\text { Value }\end{array}$ & Group A & Group B & $\begin{array}{c}P . \\
\text { Value }\end{array}$ \\
\hline MRD & $-0.79 \pm 1.21$ & $3.52 \pm 0.84$ & $<0.00$ & $-0.42 \pm 0.86$ & $3.35 \pm 0.67$ & $<0.00$ & $4.10 \pm 1.25$ & $3.80 \pm 1.10$ & 0.42 \\
\hline
\end{tabular}

\section{Cosmetic Outcomes:}

At 6 months after surgery, the number of patients in group A that showed excellent cosmetic outcomes (grade 3 on Seider's scale) were: $14 / 20$ in terms of lid contour $(70 \%), 15 / 20$ in terms of lid height symmetry $(75 \%)$ and $16 / 20$ in terms of lid crease appearance $(80 \%)$. Corresponding figures for group B patients were $(12 / 20,60 \%),(13 / 20,65 \%)$ and $(13 / 20,65 \%)$, respectively.

There were no statistically significant differences between the studied groups as regards cosmetic outcomes (Table 3).

Table (3): Comparison between the studied groups in regard to cosmetic outcomes

\begin{tabular}{|c|c|c|c|c|c|}
\hline $\begin{array}{l}\text { Groups } \\
\text { Cosmetic } \\
\text { outcome }\end{array}$ & & $\begin{array}{c}\underset{(\mathbf{n}=\mathbf{2 0})}{\text { Group A }} \\
\text {. }\end{array}$ & 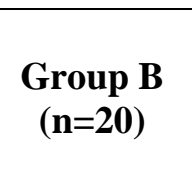 & $\begin{array}{l}\text { Total } \\
(n=40)\end{array}$ & $\begin{array}{c}P \\
\text { value }\end{array}$ \\
\hline \multirow{3}{*}{ Lid contour } & Poor & $1(5.0 \%)$ & $3(15.0 \%)$ & $4(10.0 \%)$ & \multirow{3}{*}{0.89} \\
\hline & Good & $5(25.0 \%)$ & $5(25.0 \%)$ & $10(25.0 \%)$ & \\
\hline & Excellent & $14(70.0 \%)$ & $12(60.0 \%)$ & $26(65.0 \%)$ & \\
\hline \multirow{3}{*}{$\begin{array}{l}\text { Symmetry of } \\
\text { lid height }\end{array}$} & Poor & $2(10.0 \%)$ & $2(10.0 \%)$ & $4(10.0 \%)$ & \multirow{3}{*}{0.96} \\
\hline & Good & $3(15.0 \%)$ & $5(25.0 \%)$ & $8(20.0 \%)$ & \\
\hline & Excellent & $15(75.0 \%)$ & $13(65.0 \%)$ & $28(70.0 \%)$ & \\
\hline \multirow{3}{*}{ Lid crease } & Poor & $\mathbf{0}(0.0 \%)$ & $1(5.0 \%)$ & $1(2.5 \%)$ & \multirow{3}{*}{0.79} \\
\hline & Good & $4(20.0 \%)$ & $6(30.0 \%)$ & $10(25.0 \%)$ & \\
\hline & Excellent & $16(80.0 \%)$ & $13(65.0 \%)$ & $29(72.5 \%)$ & \\
\hline
\end{tabular}

There were no statistically significant differences between the studied groups regards short-term complication and longterm complication (Table 4). 


\section{HAZEM EL-BADRY et al.,}

Table (4): Comparison between the studied groups regards short-term and longtrem complication

\begin{tabular}{|c|c|c|c|c|c|c|c|c|c|}
\hline \multicolumn{2}{|c|}{$\begin{array}{c}\text { Groups } \\
\text { Complications }\end{array}$} & \multicolumn{2}{|c|}{ Group A $(n=20)$} & \multicolumn{2}{|c|}{ Group B $(n=20)$} & \multicolumn{2}{|c|}{ Total $(n=40)$} & \multicolumn{2}{|c|}{$P$ value } \\
\hline $\begin{array}{c}\text { Short- } \\
\text { Term }\end{array}$ & $\begin{array}{l}\text { Long- } \\
\text { Term }\end{array}$ & $\begin{array}{c}\text { Short- } \\
\text { Term }\end{array}$ & $\begin{array}{l}\text { Long- } \\
\text { Term }\end{array}$ & $\begin{array}{c}\text { Short- } \\
\text { Term }\end{array}$ & $\begin{array}{l}\text { Long- } \\
\text { Term }\end{array}$ & $\begin{array}{c}\text { Short- } \\
\text { Term }\end{array}$ & $\begin{array}{l}\text { Long- } \\
\text { Term }\end{array}$ & $\begin{array}{l}\text { Short } \\
\text { Term } \\
\end{array}$ & $\begin{array}{l}\text { Long } \\
\text { Term }\end{array}$ \\
\hline NO & NO & $13(65.0 \%)$ & $14(70.0 \%)$ & $16(80.0 \%)$ & $17(85.0 \%)$ & $29(72.5 \%)$ & $31(77.5 \%)$ & \multirow{8}{*}{0.39} & \multirow{8}{*}{0.232} \\
\hline IG & D & $\mathbf{0}$ & ( $(0.0 \%)$ & $1(5.0 \%)$ & $1(5.0 \%)$ & $1(2.5 \%)$ & $1(2.5 \%)$ & & \\
\hline $\mathbf{L}$ & $\mathbf{E}$ & $1(5.0 \%)$ & $1(5.0 \%)$ & $\mathbf{0}$ & $\mathbf{0}$ & $1(2.5 \%)$ & $1(2.5 \%)$ & & \\
\hline PEE & $\mathbf{O}$ & $2(10.0 \%)$ & $0(0.0 \%)$ & $2(10.0 \%)$ & $2(10.0 \%)$ & $4(10.0 \%)$ & $1(2.5 \%)$ & & \\
\hline $\mathbf{A S}$ & $\mathbf{A S}$ & $2(10.0 \%)$ & $1(5.0 \%)$ & $\mathbf{0}$ & $\mathbf{0}$ & $2(5.0 \%)$ & $1(2.5 \%)$ & & \\
\hline T.D & TD & $1(5.0 \%)$ & $1(5.0 \%)$ & $\mathbf{0}$ & $\mathbf{0}$ & $1(2.5 \%)$ & $2(5.0 \%)$ & & \\
\hline $\mathbf{U}$ & $\mathbf{U}$ & $1(5.0 \%)$ & $1(5.0 \%)$ & 0 & $\mathbf{0}$ & $1(2.5 \%)$ & $1(2.5 \%)$ & & \\
\hline U.IG & AS.U & $\mathbf{0}$ & $0(0.0 \%)$ & $1(5.0 \%)$ & $2(10.0 \%)$ & $1(2.5 \%)$ & $2(5.0 \%)$ & & \\
\hline
\end{tabular}

No: number, IG: infective granuloma, L: Lagophthalmos, PEE: punctate epithelial erosions, U: undercorrection, D: Dermatochalesis, E: entropion U: undercorrection, TD: temporal drooping, AS: asymmetry, O: overcorrection.

\section{DISCUSSION}

Several sling materials are available, including natural materials, whether autogenously or banked such as fascia lata, temporalis fascia and scleral graft, and synthetic materials like polytetrafluoroethylene (Gore-Tex), polypropylene, nylon, silicone, and mersilene. Synthetic sling materials are more readily available and are not associated with donor-site morbidity or cross-infection possibility. However, synthetic materials are believed to have a higher recurrence rate and risk of extrusion, infection, granuloma formation, and breakage after trauma (Zaky et al., 2017).

Salama et al. (2015) compared pentagonal and monotriangular silicone slings for sever ptosis with poor levator function. Authors concluded that both sling designs were sufficient procedures to address severe congenital ptosis with poor levator function with minimal complications. Functional and cosmetic outcomes for both designs were comparable.

The triangular sling is a simple, quick procedure and favors the era of minimal surgery. With the minimal manipulations through the lid and eyebrow tissues, the triangular technique is expected to have better results with earlier recovery. In our study, we used the scleral remnant of a corneoscleral button; the triangular sling requires the least amount of sling material, it seemed ideal for our work.

There was a statistically significant difference between both groups regarding the operative time. Longer operative time was reported in group (A) because of the time consumed in harvesting fascia lata from the donor site.

Mandour et al. (2015) also reported significant drawbacks as difficulty in harvesting sufficient amount of the fascia in children younger than 3 years, and the risk of donor morbidity.

Al Taher and Awadeen (2015) Studied 23 eyelids with severe blepharoptosis, treated with frontalis suspension using autogenous fascia lata. In this study, patients developed neither intraoperative nor post-operative complications. Additionally, they attained the desired aesthetic outcomes in terms of eyelids symmetry, contour, and position. They attributed absent complications at donor 
site because they harvested the facia using small incisions that minimize the incidence of local trauma.

Mandour et al. (2015) reported donor site complications in fascia lata group were in the form of ugly thigh scar in 2 cases and herniation of the vastus lateralis muscle in one case out of 23 patients which underwent frontalis suspension using autogenous fascia lata.

We think that even small incision Fascia lata harvesting still carrying many criticisms. Presence of thigh scars is unfavorable by many parents especially for female patients. Postoperative limping, thigh pain and lengthy operation still matters.

Scleral grafts may be a suitable natural alternative for fascia lata. The material was readily available as we used the remnants of the corneoscleral button after keratoplasty. Scleral material was tougher than preserved fascia lata and supposed to behave much like corneal graft rather than preserved fascia that had absorbed. Despite promising early results, only few reports documented scleral sling ptosis repair.

To our knowledge, Bodian 1968 published the first report about scleral sling use. He reported that human scleral strips seemed particularly suitable because they are homografts and likely to be accepted by the host, readily available from eye banks, easily worked with, amenable to sterilization, preservable, and sufficiently strong. He used human scleral strips on 21 ptosis repairs followed up for 6 months. They reported recurrence in 3 cases $(14 \%)$ and there was no evidence of allergy, graft rejection, or other untoward reaction to the scleral strips.
The current study was designed to compare the results of use of autogenous fascia lata versus banked scleral graft for frontalis suspension in moderate to severe ptosis with poor levator function over 6 months follow up period. There was no significant difference regarding age, sex, ptosis type or severity; nullifying the effect of these factors on surgical outcome in both groups. Postoperative outcomes showed no significant difference regarding MRD1, $\mathrm{PFH}$, cosmetic results or complication rate in both groups.

There was a statistically significant difference between both groups regarding the operative time. Longer operative time was reported in group (A) because of the time consumed in harvesting fascia lata from the donor site.

Regarding functional outcome results, in the current study, postoperative MRD1 at follow up visits was significantly higher than the preoperative level in each group independently. This clarifies that both materials were efficient in elevating the upper eyelid significantly from preoperative level. Comparing MRD I between both groups in the follow up visits demonstrated that there was no statistically significant difference between both groups.

Our results indicated that the tensile strength of fascia lata and banked sclera remained stable at least for 6 months follow up period and we had no cases of recurrence in both groups.

Mandour et al. (2015) studied that the recurrence rate was $10 \%$ (3 eyelids) in fascia lata group. There was no statistically significant difference between both groups. However, recurrence was lower in fascia lata group. 
Regarding cosmetic outcome results, at 6 months after surgery, the number of patients in group A that showed excellent cosmetic outcomes (grade 3 on Seider's scale) were: lid contour $70 \%$, lid height symmetry $75 \%$ and lid crease appearance $80 \%$. Corresponding figures for group B patients were $60 \%, 65 \%$ and $65 \%$, respectively. Difference between both groups was statistically insignificant.

In comparison to ePTFE (GorTex), Elsamkary and Roshdy (2016) reported that fascia lata was better in lid contour and symmetry between both upper eyelids. They accounted these results that the fascia lata sheet has a good width and has better control on contour.

We reported that asymmetry was observed in 1 eyelids in group A $(5 \%)$ in group B, occurred in 2 eyelids (10\%), Temporal dropping developed in one case in group A $(5 \%)$.

Mandour et al. (2015) reported donor site complications in fascia lata group were in the form of ugly thigh scar in 2 cases and herniation of the vastus lateralis muscle in one case out of 23 patients which underwent frontalis suspension using autogenous fascia lata.

\section{CONCLUSION}

The use of autologous fascia lata was the best materials for frontalis suspension surgery due to its low complications rate and long term viability and compatibility.

Banked scleral graft in frontalis suspension was comparable to the use of autologous fascia lata with the advantage of shorter operative time and avoiding the need for a second surgical site with its potential morbidity. Follow up period of 6 months was insufficient to confirm whether scleral slings confered long lasting ptosis correction. Histopathologic study for autogenous slings, in recurrent cases, should be done to study sling changes.

\section{REFERENCES}

1. Al Taher $M$ and Awadeen A (2015): Frontalis Suspension Using Autogenous Fascia Lata For Treatment Of Severe Ptosis AMJ 13, (4 - Suppl-2), P 245-249.

2. Bodian M (1968): Repair of ptosis using human sclera. Am J ophthalmol., 65 (3): 352-358.

3. Debski T, Jethon J and Pietruski P, (2012): Frontalis suspension using autogenous fascia lata--evaluation of long-term outcome. Klinikaoczna, 114(3):198-203.

4. Elsamkary, M. A and Roshdy, M. M. S (2016): Clinical trial comparing autogenous fascia lata sling and GoreTex suspension in bilateral congenital ptosis. Clinical Ophthalmology (Auckland, NZ), 10: 405- 407.

5. Kanski JJ and Bowling B (2011): Clinical Ophthalmology; A Systematic Approach, 7th Ed. Chapter 1: Eyelids and chapter 19: Neurophthalmology. Pbl. Elsevier, Saunders, PP 81: 84.

6. Kim, J. W (2017): Neurogenic Blepharoptosis. In Evaluation and Management of Blepharoptosis (pp. 115-128). PP1. Springer New York.

7. Mandour, S. S., Marey, H. M and Rajab, G. Z (2015): Frontalis Suspension Using Autogenous Fascia Lata versus Gore-tex Sheet for Treatment of Congenital Ptosis with 
Poor Levator Function. J Clin Exp Ophthalmol., 6(396): 2-65

8. Nasr, H.E., Al Essawy, R.E., Ahmed, R.A and Soliman, A.Z (2012): Fascia Lata Frontalis Sling for Treating Congenital Ptosis: Anatomical and Cosmetic Outcomes in Monotriangular Versus Bitriangular Configuration. Med. J. Cairo Univ., 80 (2): 203-209.

9. Salama OH, Abd Al Wahab H, Abu Al-Naga AF and Tahoon GM (2015): Pentagonal versus monotriangular silicone sling for sever ptosis with poor levator function. Thesis submitted for partial fulfillment of MD degree in Ophthalmology, Faculty of Medicine, Al-Azhar University, Cairo-Egypt 2015. Central Library of Al-Azhar University; Thesis No. 20373.
10.Seider N (2011): Classification cosmetic grading scale in frontalis suspension for adult myogenic blepharoptosis.Acta Ophthalmol Scand., 84(1):121-3.

11. Zaky, A. G, Mandour, S. S., Zaky, M. A and Ebrahem, A. M. (2017): Two different techniques for frontalis suspension using Gore-Tex to treat severe congenital ptosis. Graefe's Archive for Clinical and Experimental Ophthalmology, 1-5.

12. Zhang HX, Liu $Y$ and $L$ I HK (2011): Levator shortening under microscope for treatment of congenital ptosis, Int J Ophthalmol., 54(2)134-3. 
در اسة بين إجر اء جر احي إستخدام الحافة النجلية للفافة

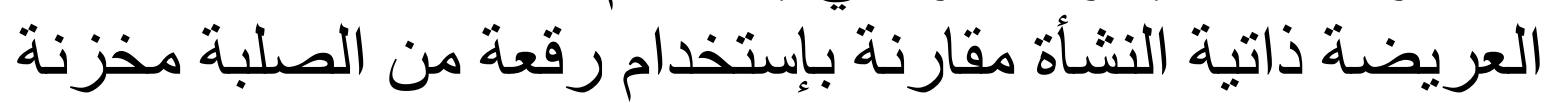

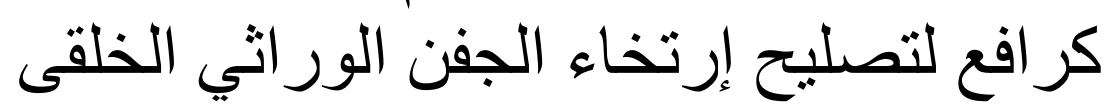
حازم البدرى محمد, حسنى حسن محمد, عمر حسن سلامة قسم طب وجراحة العيون، كلية الطب، جامعة الأزهر بالقاهرة

E-mail: ophthalomologisthazem@gmail.com

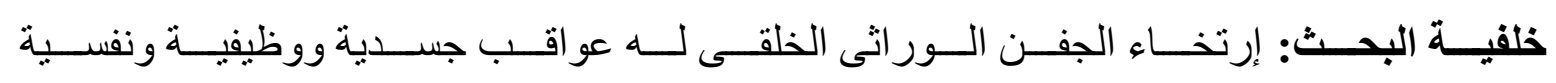

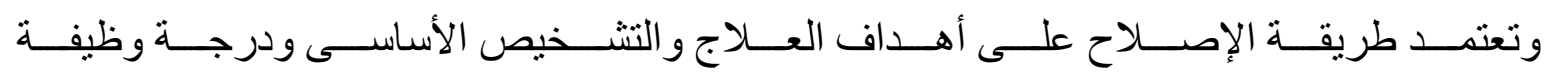

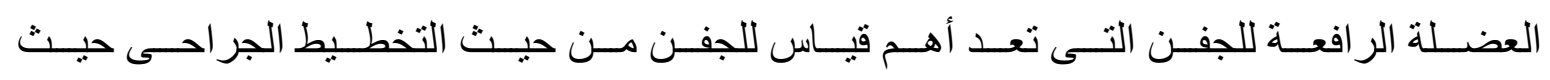

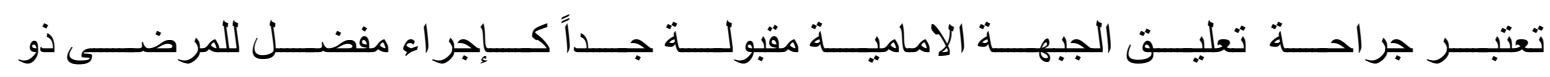

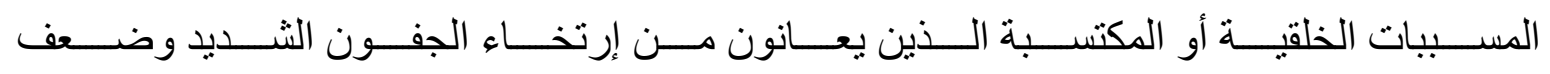

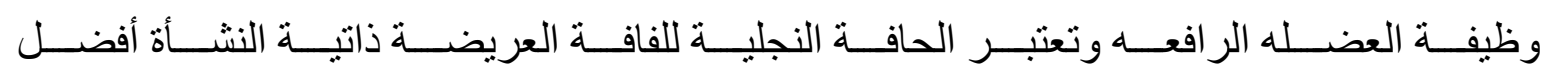

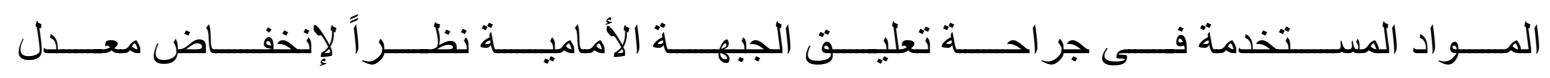

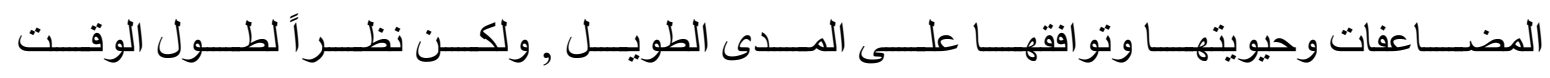

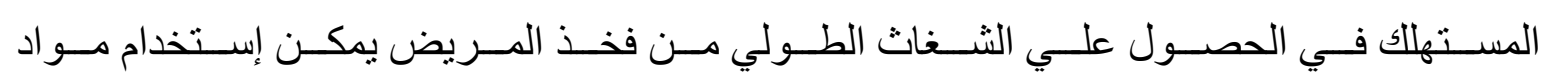

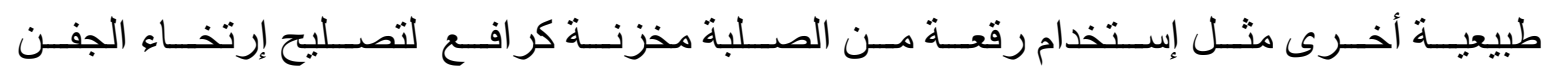
الور اثي الخلقى.

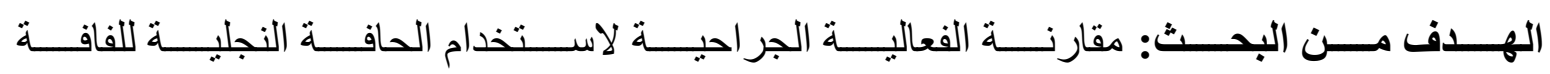

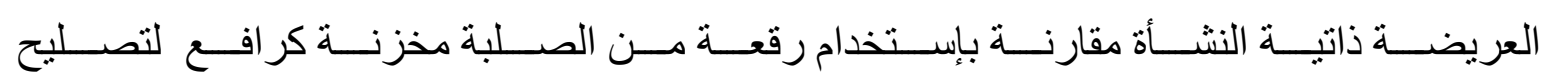
ارتخاء الجفن الوراثي الخلقى.

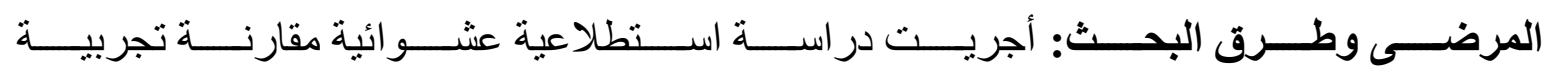

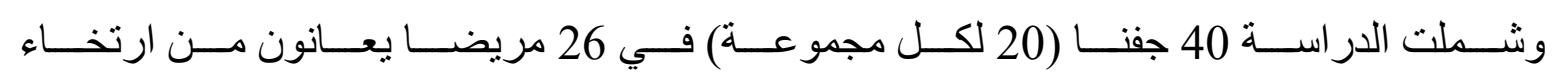

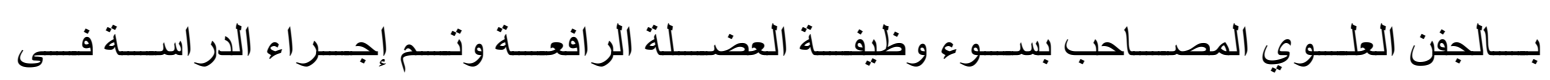

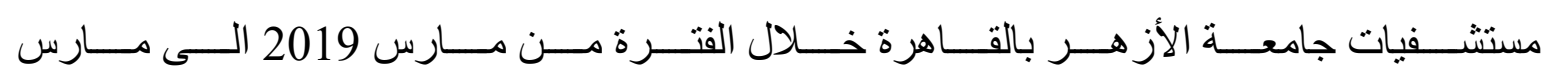

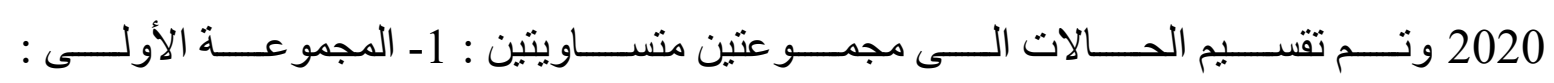

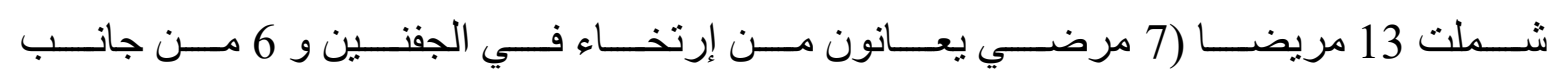




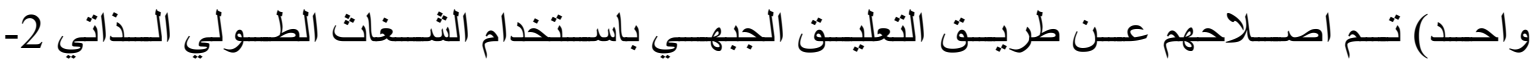

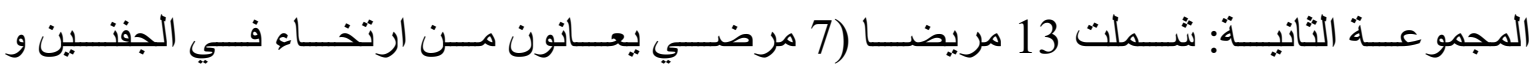

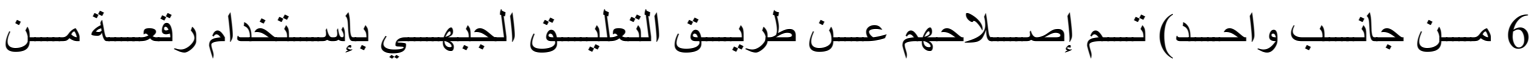

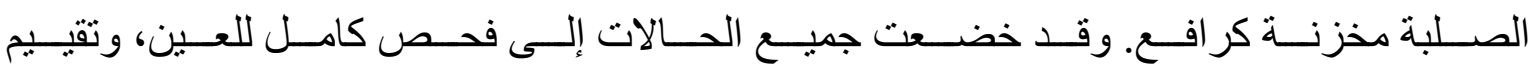

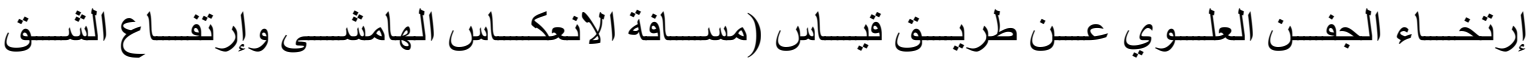

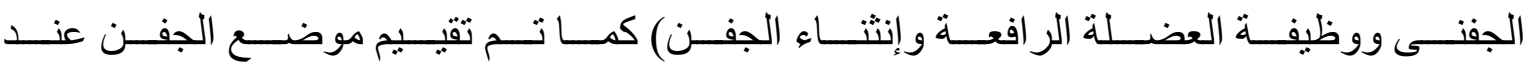

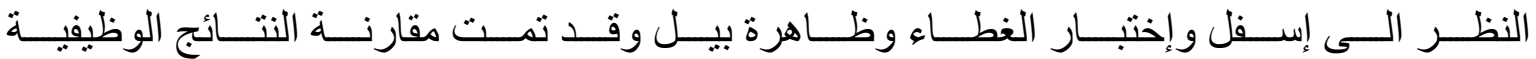
و النتائج التجميلية ومعدل المضاعفات.

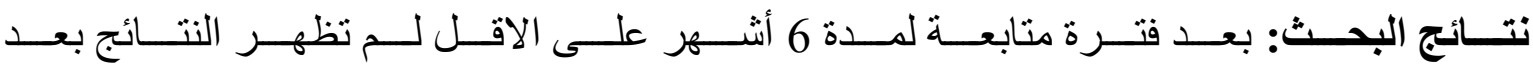

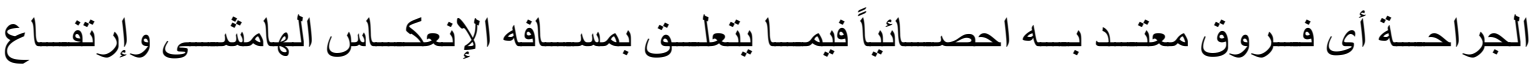

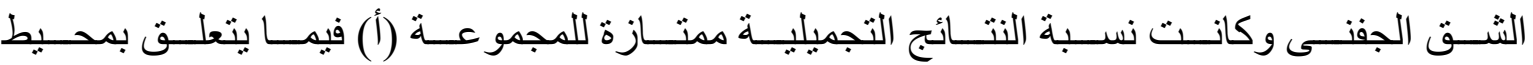

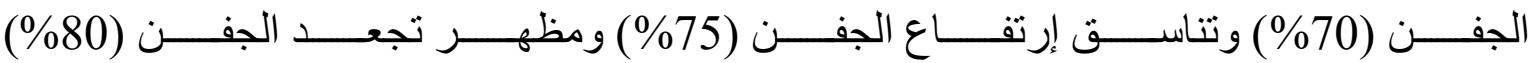

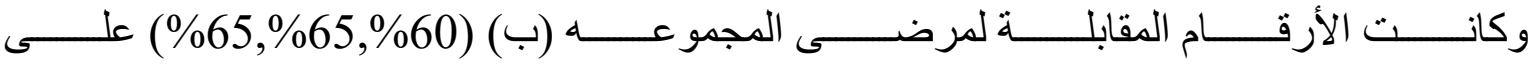
التو الى ولم تحدث بإى حالة أى مضاعفات خطيرة.

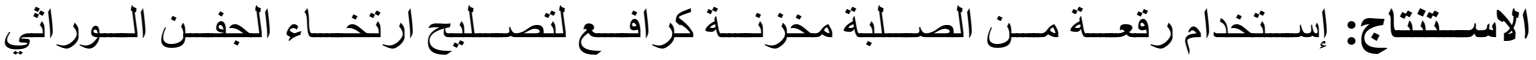

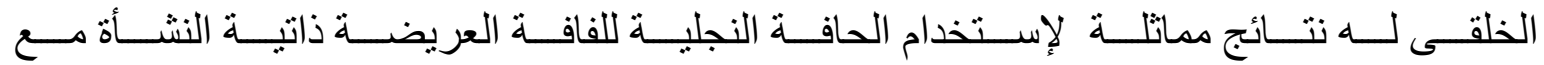

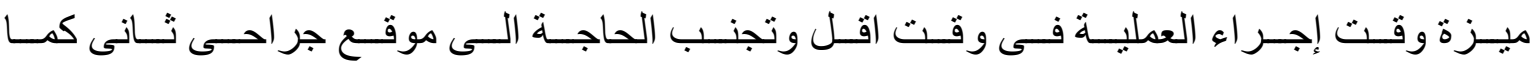

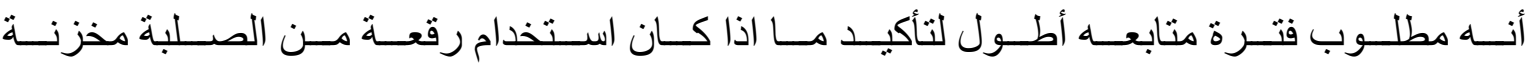

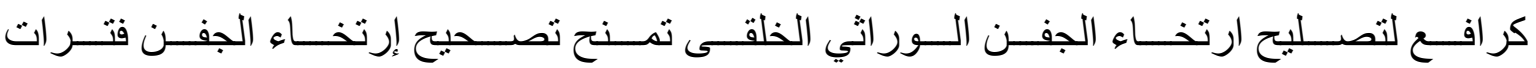

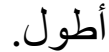

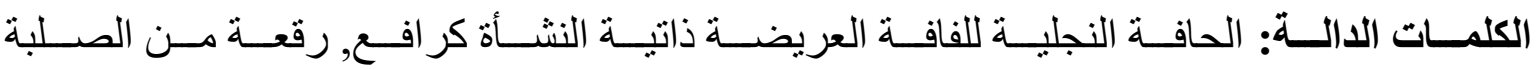
مخزنة كر افع, الجفن الور اثتي الخلقى. 